\title{
The Present Situation of Sino - Thai Trade and the Enlightenment from the Belt and Road Construction
}

\author{
Shuai $\mathrm{Lu}$ \\ Finance School \\ Yunnan University of Finance and Economics \\ Kunming, China \\ 791810436@qq.com
}

Meng Sun *

Business School

\author{
Jin Chen \\ Business School \\ Yunnan University of Finance and Economics \\ Kunming, China \\ 644726534@qq.com \\ Yunnan University of Finance and Economics \\ Kunming, China \\ 493435756@qq.com
}

\begin{abstract}
Since the establishment of diplomatic relations between China and Thailand, the trade exchanges between China and Thailand have become more frequent, which have brought about many problems such as unbalanced trade and information asymmetry while promoting the economic development of both countries and bringing benefits to their peoples. These problems have hindered the stable and healthy development of trade and other aspects of cooperation between the two countries. The idea and implementation of the Belt and Road initiative put forward a significant solution to the Sino-Thai trade problems. This article aims to analyze the current status of trade between China and Thailand and, in combination with the strategic vision and realistic basis for the Belt and Road, propose some countermeasures and suggestions against the existing problems in trade between China and Thailand.
\end{abstract}

Keywords-China-Thailand trade; Belt and Road; ASEAN; international trade

\section{INTRODUCTION}

On September 7, 2013, President Xi Jinping proposed for the first time an initiative to jointly build the 'Silk Road Economic Belt' with all Eurasian countries in his speech in Kazakhstan. On the same year, on October 3, President Xi Jinping issued a statement in the Indonesian Parliament In his speech, and he said that China is willing to work together with ASEAN countries to build the 21st Century Maritime Silk Road [1].

ASEAN is an vital development direction and an important cooperative area of the "One Belt and One Road" construction. As early as 1991, the two sides started a political dialogue. At the economic level, the two sides signed the Framework Agreement on Comprehensive Economic Cooperation between China and ASEAN in November 2002, and decided to establish the China-ASEAN Free Trade Area by 2010 , officially starting the process of building the China-ASEAN Free Trade Area which has been successfully built up and moving toward a more open and positive direction[2]. Building a closer the China-ASEAN community of shared future will not only lay a solid foundation for the long-term friendly cooperation between the two sides, but also provide a rare opportunity to the two sides to dock both development strategies. It will also contribute to the continuous development of the "Belt and Road" in diverse ways [3]. The strategic concept of "One Belt and One Road" has a positive impact on the smooth flow of trade between China and Thailand, the interconnection of countries along the route, the promotion of Sino-Thai cultural exchanges and strengthening of financial cooperation among nations. Thailand is another important link in ASEAN. China-Thailand cooperation can further deepen China's cooperation with Indochina Peninsula and strengthen China-ASEAN partnership.

\section{LITERATURE REVIEW}

Researches Related to Sino-Thai Trade:

At present, there are mainly qualitative and empirical studies on the trade between China and Thailand. Most qualitative analysis analyze the status quo of trade between China and Thailand and identify the inherent problems to generate the relevant policy recommendations and prospects.

Zhou Zhongjian of Institute of Southeast Asian Studies, Guangxi Academy of Social Sciences published an article entitled "A Brief History of the Development of Sino-Thai Economic and Trade Relations" in "Southeast Asia" in 1988.In his research, he pointed out in his research that there was only a small amount of non-governmental exchanges between China and Thailand between 1950 and 1958. In 1959-1973, the trade between the two sides was suspended due to deteriorating relations. After continuous efforts by both countries and China's reforms of the opening up, the impact of economic development, it "like the tide after opening the floodgates, inexorably flowed forward" [4]. The trade between China and Thailand ushers in a new wave of development.

Zhou Wei analyzed the dynamic and asymmetric contagion reactions of financial markets during the last

*Corresponding author 
subprime crisis [5]. Based on it, we can analyze the slowdown of trade growth around the year 2008. He also presented an iterative optimization algorithm to improve their expected consistency [6].

Chen Ding of Xi'an Petroleum University in 2016 and Lu Shanbing of Northwestern University published" the Impact Mechanism of Sino-Thai FDI on Bilateral Trade against the backdrop of 'One Belt and One Road' " in the Hebei Academic Journal. This article analyzed the relationship between China and Thailand's FDI and foreign direct investment and the status quo of bilateral trade, fully develop the potential and optimize the structure of FDI, that can be used to construct a model with limited samples to provide better forecasting advantage for short-term problems [7], thus contributing to the mutually beneficial win-win cooperation between China and Thailand in the trade cooperation.

Literature Review: In summary, trade between China and Thailand has always been a central issue for scholars. In recent years, with the ever-increasing cooperation and exchanges between China and Thailand and changes in the world situation, the trade between China and Thailand and the Belt and Road has been changing all the time. Both China and Thailand have ushered in new opportunities and challenges. Therefore, the scholars' research has reference significance to this topic.

\section{Sino-Thai Trade Status}

\section{A. Total trade and deficit}

During 1949-1974, China and Thailand have not yet established diplomatic relations. Due to the political relations between the two countries, the bilateral economic and trade cooperation was limited to non-governmental exchanges. the two nations are almost in isolation from each other until in the years of 1955-1957,during which the iceberg began to melt and the tension between the two countries temporarily eased off [8],the bilateral trade was intermittent and the trade volume was extremely small. With the establishment in 1975 of diplomatic ties, a new page opened up in the annuals of modern Sino-Thai relations [9], the frequency of trade between the two countries had greatly increased. In recent years, the two countries have maintained a steady and vigorous development. Especially after 1992, the trade between the two countries showed a steady and substantial increase. It argues that after China WTO entry, Thai exports to China will increase significantly and Sino-Thai trade deficit is likely to further enlarge, enabling Thailand to benefit a great deal in the short run[10]. It then outlooks the future developmental trend, which is that the "tariff-free" agreement, together with every effort of both sides, will be further implemented, greater win-win achievements will be made and its future is bright. The paper also suggests solutions to the problems to promote the overall development in such trade [11]. The establishment of CAFTA provides a broad space for the development of Sino-Thai trade and economic cooperation. an FTA approximately doubles two members' bilateral trade after 10 years [12]. Deepen financial cooperation is an extension of the increasingly close bilateral economic and trade relations [13].

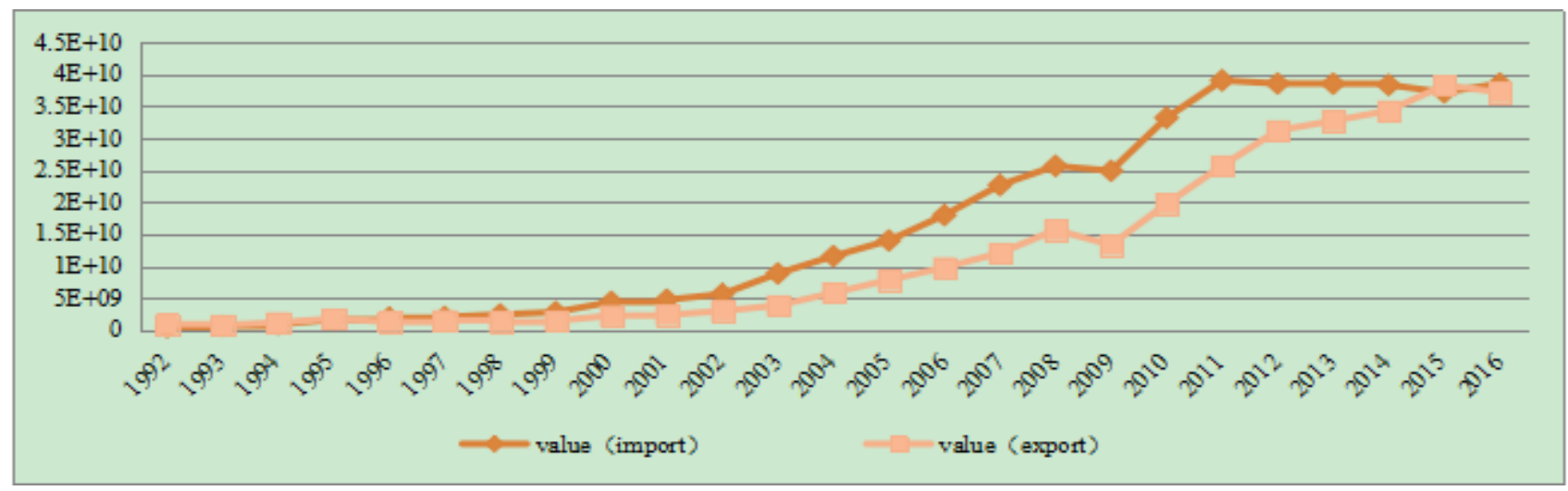

Fig. 1. China trade in Total of all HS commodities with Thailand since 1992

According to Thai customs statistics, January-September 2017, Thailand's import and export of goods amounted to 340.38 billion U.S. dollars, up $12.1 \%$ over the same period of last year (the same below). Besides, exports reached 175.18 billion U.S. dollars, up 9.7 percent; Imports reached 165.2 billion U.S. dollars, up 14.9 percent. Favorable Balance of Trade reaches 9.98 billion US dollars, down $37.2 \%$.

From January to September, Thailand exported 16.39 billion U.S. dollars and 19.66 billion U.S. dollars respectively, up $8.5 \%$ and $7.8 \%$ respectively. The total value of the two countries' exports to Thailand $20.6 \%$; imported 23.89 billion
U.S. dollars and 11.4 billion U.S. dollars from both countries, up $3.5 \%$ and $30.6 \%$ respectively, accounting for $14.5 \%$ and $6.9 \%$ of Thailand's total imports. The United States is Thailand's largest source of trade surpluses. The surplus from January to September was 8.27 billion U.S. dollars, down $13.1 \%$. Thailand's trade deficit mainly come from China and Japan, with the deficit from January to September of 11.48 billion U.S. dollars and the deficit of 7.5 billion U.S. dollars. 


\section{B. Import and Export}

TABLE I. THAILAND'S EXPORT TO MAJOR TRADING PARTNERS

\begin{tabular}{|l|c|c|c|}
\hline \multicolumn{4}{|c|}{$(1-9$ months of 2017) a unit of amount: millions of dollars } \\
\hline $\begin{array}{l}\text { Countries and } \\
\text { regions }\end{array}$ & Amount of money & Year-on-year\% & Proportion \% \\
\hline China & 21,331 & 28.7 & 12.2 \\
\hline U.S.A & 19,664 & 7.8 & 11.2 \\
\hline Japan & 16,392 & 8.5 & 9.4 \\
\hline Hong Kong & 9,339 & 9.1 & 5.3 \\
\hline Vietnam & 8,277 & 25.4 & 4.7 \\
\hline Australia & 7,779 & -2.1 & 4.4 \\
\hline Malaysia & 7,546 & 5 & 4.3 \\
\hline Indonesia & 6,626 & 5.8 & 3.8 \\
\hline Singapore & 6,279 & 2.4 & 3.6 \\
\hline Philippines & 5,013 & 5.4 & 2.9 \\
\hline India & 4,707 & 20 & 2.7 \\
\hline Switzerland & 3,886 & -12.4 & 2.2 \\
\hline Cambodia & 3,680 & 18.3 & 2.1 \\
\hline Germany & 3,648 & 7.1 & 2.1 \\
\hline Korea & 3,549 & 20.9 & 2 \\
\hline Gross value & 175,180 & 9.7 & 100 \\
\hline
\end{tabular}

TABLE II. THAILAND'S IMPORTS FROM MAJOR TRADING PARTNERS

\begin{tabular}{|l|l|l|l|}
\hline \multicolumn{3}{|c|}{$(1-9$ months of 2017) } & unit of amount: millions of dollars \\
\hline $\begin{array}{l}\text { Countries and } \\
\text { regions }\end{array}$ & Amount of money & Year-on-year\% & Proportion \% \\
\hline China & 32,808 & 4.7 & 19.9 \\
\hline Japan & 23,893 & 3.5 & 14.5 \\
\hline U.S.A & 11,398 & 30.6 & 6.9 \\
\hline Malaysia & 8,746 & 7.3 & 5.3 \\
\hline $\begin{array}{l}\text { Taiwan } \\
\text { Province }\end{array}$ & 6,202 & 16.6 & 3.8 \\
\hline Korea & 6,129 & 12.5 & 3.7 \\
\hline Singapore & 6,075 & 23.8 & 3.7 \\
\hline Indonesia & 5,558 & 16 & 3.4 \\
\hline $\begin{array}{l}\text { The United } \\
\text { Arab Emirates }\end{array}$ & 5,375 & 20 & 3.3 \\
\hline Switzerland & 5,049 & 96.6 & 3.1 \\
\hline Germany & 4,520 & 3.5 & 2.7 \\
\hline Saudi Arabia & 4,518 & 31.2 & 2.7 \\
\hline Vietnam & 3,681 & 10.3 & 2.2 \\
\hline Australia & 3,075 & 40.1 & 1.9 \\
\hline India & 2,868 & 52.3 & 1.7 \\
\hline Gross value & 165,198 & 14.9 & 100 \\
\hline & & & \\
\hline
\end{tabular}

January-September 2017, what is shown in Table I and Table II respectively is Thailand's import and export to its major trading partners from January to September in2017. We can observe that the main countries are China, Vietnam, South Korea, India and Cambodia. From January to September 2017, Thailand's total exports to China amounted to US \$ 21331 million, still achieving very high growth rates on the basis of a huge base. On the import aspect, Switzerland, India, Australia, Saudi Arabia and the United States rank among the top five countries in the same period in terms of Thailand's imports. Among them, India and Saudi Arabia are the countries along the Belt and Road. With a $19.9 \%$ share of Thailand's imports, there is still a year-on-year increase of $4.7 \%$.

\section{Sino-Thai Trade Problems}

The status is unbalanced status trends. China is currently Thailand's largest trading partner, with trade data for 2016 indicating that China is Thailand's second largest export market (11.0\% of Thailand's exports) and Thailand's largest import market (21.6\% of Thailand's imports). Thailand is the fifteenth largest export market in China $(1.8 \%$ of China's exports) and the 11th largest import market in China (2.4\% of China's imports) [14]. Moreover, with the rapid growth of China's comprehensive national strength and rising international influence, China's total trade volume has been growing while that of China's import and export volume to China's total import and export volume has also dropped, showing Thailand's high dependence on China and the uneven trade status between the two countries.

Thailand's trade exists deficit, meanwhile the level of trade in goods is low. As an economically developing country, Thailand needs to expand its export to Increase the balance of payments which is still an important source [15]. Expanding its long-term huge trade deficit will inevitably exacerbate its imbalance in foreign exchange receipts and payments, causing many negative impacts on the sustainability and reciprocity of bilateral trade which counts against the long-term and healthy development of bilateral trade cooperation between China and Thailand.

Interoperability is low. Although China and Thailand have implemented zero-tariff customs policies, their capacity for interoperability is not satisfactory due to Thailand's relatively backward infrastructure construction [16]. Due to the constraints of technology constraints, insufficient reserve of qualified personnel and poor financing conditions in Thailand, it is very difficult to carry out related construction without external support.

\section{RELEVANT COUNTERMEASURES AND ENLIGHTENMENT BROUGHT BY BELT AND ROAD}

It is necessary to improve the trade imbalance between China and Thailand, promoting political mutual trust, advancing multi-level intergovernmental exchanges and strengthening intergovernmental cooperation are also essential [17]. Promoting the integration of the interests of the two countries and reaching a new consensus on cooperation will assist the two countries to form deeper trade cooperation [18]. In addition, the full exchange between the two countries and other countries along the line and the formulation of suitable development strategies for regional cooperation and the introduction of relevant trade policies will also accelerate the speed to resolve the imbalance issues between international trade.

In consideration of the trade deficit and the level of trade commodities, the two countries should link international trade and industrial upgrading [19] to broaden the scope of trade. As far as Thailand is concerned, it should take full advantage of its exports of agricultural products and improve the industrial structure, enrich the industrial level and develop the industrial depth so as to enhance the competitiveness of the agricultural products industry such as rice, natural rubber, timber, tropical fruits and vegetables and create more added 
value to attract more agricultural investment. Sino-Thailand bilateral agriculture trade is perfectly complementary. It has a good potential and will necessarily keep increasing [20]. In the manufacturing sector, a strategy of "investment-led trade" should be implemented to attract more direct investment while strengthening input in scientific and technological innovation and improving product quality and technological content. For China, excess liquidity, ignited by dramatic capital inflows, is a significant driver for consumer price inflation in China during the last decade [21]. In the meantime, China should continuously raise the level and content of manufactured goods, enhance the complementarity of trade between the two countries and polish up the trade structure.

The interconnection of infrastructure not only provides convenient conditions for the development of Sino-Thai economic and trade cooperation, but also serves as an important prerequisite and an objective basis for promoting exchanges between the two countries. China-Thailand railway construction cooperation is an vital practice of China in advancing the "One Belt and One Road" initiative in Southeast Asia. Therefore, continuing to push forward the construction of infrastructure facilities is of great significance to the establishment of Thailand as a regional interconnection hub and an important economic center for ASEAN, as well as the practice of building the Belt and Road Initiative in all Southeast Asian countries [22].

\section{CONCLUSION}

China and Thailand have formed bilateral cooperation in the long-term relationship based on equality, mutual benefit and trade. Despite the existence of trade imbalances, large trade deficits and weak interoperability, the trade between China and Thailand has shown vibrant growing trend. The Belt and Road Initiative has brought some new revelations and measures to solve the problems in trade between China and Thailand. Under the background of the new policy and the healthy development of the international situation, ,constructing a full range and multi-level communication coordination network of One Belt One Road will help to further reinforce the basis of Sino-Thai strategic cooperation [23], both China and Thailand should augment communication and cooperation between the two governments, broaden the fields of cooperation and promote Bilateral trade facilitation and the growth of bilateral trade and investment. In addition, we should also further international dialogue and work hand in hand to achieve the goal of common development and common prosperity along the Belt and Road.

\section{ACKNOWLEDGEMENTS}

This work was supported by the Natural Science Foundation of China [No.71561026]; and Applied Basic Research Programs of Science and Technology Commission of Yunnan Province [No. 2017FB102]

\section{REFERENCES}

[1] J. R. Lu, “"Belt and Road Initiative” and China-ASEAN Destiny Community Construction," Innovation, 2015, pp. 44-50.

[2] J. Chen, J.J He and Z. W. Wang, etc, "The Key Points to Promote the Financial Cooperation between China and the Belt and Road ASEAN Countries ,'West Finance, 2017,pp. 16-20.

[3] J. H .Zhang and H. Lin , ““'The Belt and Road" to inject new impetus to the win-win cooperation between China and ASEAN ," Xinhua News Agency, 2016-09-12 09:48

[4] Z.J. Zhou, "From low to high tide-- Overview of the development and history of Sino-Thai economic and trade relations," History of Southeast Asia, 1988 ,pp.37-42.

[5] Zhou W. Dynamic and asymmetric contagion reactions of financial markets during the last subprime crisis. Computational Economics, 2017, 50(2): 207-230.

[6] Zhou W, Xu Z. Probability calculation and element optimization of probabilistic hesitant fuzzy preference relations based on expected consistency. IEEE Transactions on Fuzzy Systems, 2018, 26(3): 1367-1378.

[7] Zhou W, He J. Generalized GM $(1,1)$ model and its application in forecasting of fuel production. Applied Mathematical Modelling, 2013, 37(9): 6234-6243.

[8] Huang, R. Z, "Reasons behind the Mid-50s Thailand-China Relations - from Tension to Relaxation," Southeast Asian Studies, 2008

[9] "Blossoming SINO-THAI Friendship In 20 Years," Modern International Relations (English), 1995 ,pp.11-18.

[10] Xu. K, "Impacts of China WTO Entry on Sino-Thai Trade," Southeast Asian Affairs, 2002.

[11] Luo. Y. Y, "The Present Situation and Outlook of the Sino-Thai Fruit and Vegetable Trade after the Signing of the "Tariff-Free" Agreement, "All-round Southeast Asia ,2005.

[12] Zhou W, Xu Z. Generalized asymmetric linguistic term set and its application to qualitative decision making involving risk appetites. European Journal of Operational Research, 2016, 254: 610-621.

[13] Zhou W, Xu Z. Expected hesitant VaR for tail decision making under probabilistic hesitant fuzzy environment. Applied Soft Computing, 2017, 60: 297-311

[14] Zhou W, Xu Z. Portfolio selection and risk investment under the hesitant fuzzy environment. Knowledge-Based Systems, 2018. 144: 21-31.

[15] Zhou W, Xu Z. Group consistency and group decision making under uncertain probabilistic hesitant fuzzy preference environment. Information Sciences, 2017, 414: 276-288.

[16] Baier. S.L, Bergstrand. J.H, "Do free trade agreements actually increase members' international trade? "Journal of International Economics, 2005, pp.72-95.

[17] Yan. L.I and SO. Finance, "A Study on Sino-Thai Financial Cooperation under the Framework of CAFTA," Research of Finance \& Education ,2014.

[18] Jinghua You, "CAFTA after zero-tariff agricultural products trade between Thailand and China ," University of International Business and Economics, 2013.

[19] G. Gereffi, "International trade and industrial upgrading in the apparel commodity chain,” Journal of International Economics,1999, pp,37-70.

[20] Yin. X and X. Zhou, "Sino-Thailand bilateral trade in agricultural products competition and complement, "Metallurgical \& Mining Industry ,2015.

[21] Zhang.C, "Excess Liquidity, Inflation and the Yuan Appreciation: What Can China Learn from Recent History? ," World Economy, 2009, pp,998-1018.

[22] Zhou. F. Y, "One Belt One Road and Sino-Thai Strategic Cooperation: Opportunities, Challenges and Recommendations," Southeast Asian Affairs, 2016. 
[23] Xu, P.Y., Liu, Y.F. "Study on the Current Situation, Problems and Countermeasures of the Economic Relationship between China and
Thailand ," Japanese Economics, 2017 ,pp.23-3 